\title{
Greek liturgy in crusader Jerusalem: witnesses of liturgical life at the Holy Sepulchre and St Sabas Lavra
}

\section{Daniel Galadza}

To cite this article: Daniel Galadza (2017) Greek liturgy in crusader Jerusalem: witnesses of liturgical life at the Holy Sepulchre and St Sabas Lavra, Journal of Medieval History, 43:4, 421-437, DOI: $10.1080 / 03044181.2017 .1346935$

To link to this article: https://doi.org/10.1080/03044181.2017.1346935

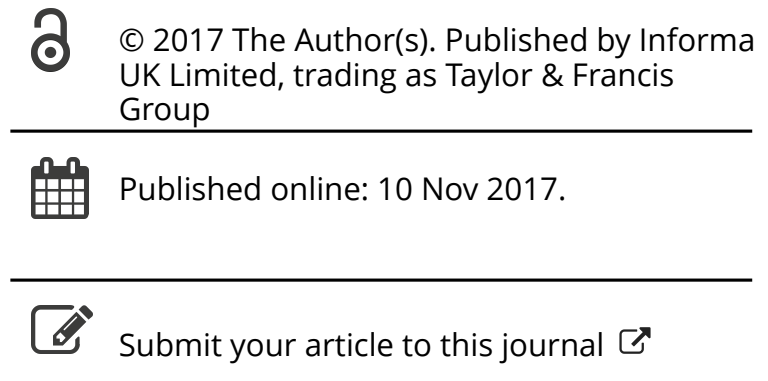

Џ Article views: 517

\section{Q View related articles $\square$}

\section{View Crossmark data $\longleftarrow$}




\section{Greek liturgy in crusader Jerusalem: witnesses of liturgical life at the Holy Sepulchre and St Sabas Lavra}

\section{Daniel Galadza}

Institut für Historische Theologie, Liturgiewissenschaft und Sakramententheologie, Universität Wien, Vienna, Austria

\begin{abstract}
Although the arrival of the crusaders in Jerusalem in 1099 displaced the clergy, monks and faithful of the Orthodox Patriarchate of Jerusalem from the holy sites that had been in their care for almost 800 years, they continued to pray and worship in the territory of the Latin Kingdom of Jerusalem. This article examines two Greek liturgical manuscripts copied in Palestine during the twelfth century and seeks to contextualise their liturgical practices. The first manuscript, Hagios Stavros Gr. 43 (A.D. 1122), referred to as the 'Anastasis Typikon', is a hymnal for Holy Week and Easter at the Church of the Holy Sepulchre. The second manuscript, Sinai Gr. 1096 (twelfth century), is a liturgical Typikon regulating services at the multi-lingual and multi-ethnic Lavra of Mar Sabas south-east of Jerusalem. While both manuscripts are significant witnesses to the development of the Byzantine rite, they also provide glimpses of the religious life of Greek-praying Christians under crusader rule.
\end{abstract}

\section{ARTICLE HISTORY}

Received 2 March 2017

Accepted 19 April 2017

\section{KEYWORDS}

Byzantine liturgy; Mar Sabas

Lavra; Holy Sepulchre;

Typikon; Palestinian

monasticism; Orthodox

Christianity; Greek

manuscripts

\section{Introduction}

To say that the arrival of the crusaders in Jerusalem in 1099 was cataclysmic for the clergy, monks and faithful of the Orthodox Patriarchate of Jerusalem would be an understatement. For the first time in nearly 800 years, the local Orthodox Christians of Jerusalem were displaced from the holy sites they had in their care and were now no longer a Christian majority under Muslim rule, but rather under the rule of foreign Christians of another jurisdiction. Despite this change, the local Christians continued to pray and worship in the territory of the Latin Kingdom of Jerusalem as, so to speak, 'second-class citizens'. While the role of prayer and worship among Western Christians has received attention in histories of the crusaders - and this field is now expanding ${ }^{1}$ - the same cannot be said for

CONTACT Daniel Galadza daniel.galadza@univie.ac.at $\mathrm{E}$ Institut für Historische Theologie - Liturgiewissenschaft und Sakramententheologie, Universität Wien, Schenkenstraße 8-10, Vienna 1010, Austria

${ }^{1}$ The following abbreviations are used in this paper: BnF: Paris, Bibliothèque nationale de France; CPG: Maurice Geerard, Clavis patrum Graecorum qua optimae quaeque scriptorium patrum Graecorum recensiones a primaevis saeculis usque ad octavum commode recluduntur. 6 vols. (Turnhout: Brepols, 1974-2003); CSCO: Corpus Scriptorum Christianorum Orientalium; Dondi, Liturgy: Cristina Dondi, The Liturgy of the Canons Regular of the Holy Sepulchre of Jerusalem: a Study and a Catalogue of the Manuscript Sources (Turnhout: Brepols, 2004); Kohler, 'Un rituel':

(c) 2017 The Author(s). Published by Informa UK Limited, trading as Taylor \& Francis Group

This is an Open Access article distributed under the terms of the Creative Commons Attribution-NonCommercial-NoDerivatives License (http://creativecommons.org/licenses/by-nc-nd/4.0/), which permits non-commercial re-use, distribution, and reproduction in any medium, provided the original work is properly cited, and is not altered, transformed, or built upon in any way. 
Greek prayer and worship within the Latin Kingdom of Jerusalem. What little is known of twelfth-century Greek liturgical practices in Palestine is rarely put into the context of crusader Jerusalem. Instead, when it is examined, it is done within the greater context of the Byzantine rite, viewing Jerusalem's Greek liturgy in relation to other contemporaneous Greek liturgies - for example in relation to Constantinople or Mount Athos - but often without considering the local context in which it was being celebrated. ${ }^{2}$

The purpose of this article, therefore, is to look at the other side of the coin: to understand how Greek-praying Christians continued to worship in Palestine after the arrival of the crusaders. The twelfth century has yielded two extremely significant Greek liturgical manuscripts from Palestine to facilitate such a study, namely Hagios Stavros Gr. 43 (A.D. 1122) and Sinai Gr. 1096 (twelfth century). ${ }^{3}$ The former is an important, albeit problematic, hymnal of cathedral liturgy in Jerusalem at the Church of the Holy Sepulchre, or the Anastasis, for the celebrations of Holy Week and Easter and contains hymns proper to the city of Jerusalem, while the latter is a monastic Typikon, or ordo, regulating monastic life and the liturgical services of St Sabas Lavra, located approximately $14.5 \mathrm{~km}$ south-east of Jerusalem in the Judaean Desert. These two manuscripts reveal the important role liturgy played in preserving and/or forming the identity of Orthodox Christians in crusader Jerusalem in both urban cathedral and desert monastic settings during a time when tendencies of 'liturgical Byzantinisation' and 'cultural Arabisation' were reaching their climax.

Before examining the twelfth century, the paper offers a brief overview of Jerusalem's liturgy from the seventh to eleventh century; it then looks at the state of Orthodox Christians in crusader Jerusalem; and finally turns to the two manuscripts of cathedral and monastic liturgy that are the focus of this paper.

\section{Greek liturgy in Jerusalem (seventh to eleventh centuries)}

Any discussion of Jerusalem's liturgy would be incomplete without citing the fourthcentury pilgrim Egeria's travel diary and her dictum that the hymns, prayers and scriptural readings from Jerusalem's liturgy were always appropriate to the time and place. ${ }^{4}$ This

Charles Kohler, 'Un rituel et un breviaire du Saint-Sépulcre de Jérusalem (XIIe-XIIIe siècle)', Revue de l'Orient Latin 8 (1900-1): 383-500; PG: Patrologia cursus completus series Graeca; Salvadó, 'Liturgy of the Holy Sepulchre': Sebastián Salvadó, 'The Liturgy of the Holy Sepulchre and the Templar Rite: Edition and Analysis of the Jerusalem Ordinal (Rome, Bib. Vat., Barb. Lat. 659) with a Comparative Study of the Acre Breviary (Paris, Bib. Nat., MS Latin 10478)' (Ph.D. diss., Stanford University, 2011).

See, for example, Kohler, 'Un rituel', 383-500. More recent studies include Dondi, Liturgy, and Salvadó, 'Liturgy of the Holy Sepulchre'. S. Salvadó, 'Rewriting the Latin liturgy of the Holy Sepulchre: Text, Ritual and Devotion for 1149', in this special issue, Journal of Medieval History 43, no. 4 (2017): 403-420.

${ }^{2}$ For an analysis of Greek liturgy in Byzantium during the twelfth century, see Robert F. Taft, 'Mount Athos: a Late Chapter in the History of the Byzantine Rite', Dumbarton Oaks Papers 42 (1988): 179-94.

3 These manuscripts are currently found at the Library of the Greek Orthodox Patriarchate of Jerusalem and the Library of the Monastery of St Catherine on Mount Sinai, respectively. See Kenneth W. Clark, Checklist of Manuscripts in the Libraries of the Greek and Armenian Patriarchates in Jerusalem. Microfilmed for the Library of Congress, 1949-1950 (Washington, DC: Library of Congress, 1953), 14; Murad Kamil, Catalogue of All Manuscripts in the Monastery of St Catherine on Mount Sinai (Wiesbaden: Otto Harrassowitz, 1970), 117. For the dating of Sinai Gr. 1096, I follow Alexei A. Dmitrievskii, Описаніе литургическихъ рукописей, хранящихся въ библіотекахъ православнаго востока, vol. 3, Тvлıка́ (St Petersburg: Типографія В.Ө. Киршбаума, 1917), 20.

${ }^{4}$ Égérie, Journal de voyage (Itinéraire), ed. Pierre Maraval. Sources chrétiennes 296 (Paris: Cerf, 1982), 252 (25: 10) and 268 (29: 2): 'Et quoniam dum predicant, vel elegent singulas lectiones vel dicunt ymnos, omnia tamen apta ipsi diei ...' (25: 10); 'Dicuntur autem totis vigiliis apti psalmi semper vel antiphonae tam loco quam diei' (29: 2); 'Illud autem hic ante omnia valde gratum fit et valde admirabile, ut semper tam ymni quam antiphonae et lectiones nec non etiam et orationes, quas dicet episcopus, tales pronuntiationes habeant, ut et diei, qui celebratur, et loco, in quo agitur, aptae et convenientes sint semper' (47: 5). 
principle continued to hold true for Jerusalem for several centuries. The Holy City's - hence the Greek adjective, 'hagiopolite', meaning 'of the Holy City' - original Eucharistic liturgy attributed to St James, the Brother of the Lord, specifically mentions 'Sion, the mother of all Churches' and prays for the holy places of Christ in its central prayer of the Eucharistic liturgy, the Anaphora of St James, while the liturgy's litanies, i.e. petitions proclaimed by the deacon at various points during liturgical services, always mentioned local saints, such as John the Baptist, Protomartyr Stephen, Prophets Elias, Eliseus, Samuel and David, and others. ${ }^{5}$ The liturgical calendar celebrated these local saints on days of particular importance to the Church of Jerusalem. Shrines in their honour dotted the topography of the Holy City, creating a 'sacred topography' that was often imitated in other cities, such as Constantinople or Rome, but could never be duplicated there. The lectionary was also specific to Jerusalem and provided the themes for hymnography at the Eucharistic liturgy of St James. Overall, the liturgy of Jerusalem in Late Antiquity was very strongly tied to place and time, and this unified system was strongly marked by its local character. ${ }^{6}$

But trouble was looming on the horizon for the liturgy of Jerusalem. Fallout from the Christological controversies after the Council of Chalcedon in 451 formed divisions in the Jerusalem patriarchate and the problems of Origenism caused rifts even within Palestinian monasticism. Imperial intervention from Constantinople in the sixth century forced Jerusalem to adopt certain holidays, such as Christmas on 25 December and Hypapante, the Presentation of Christ in the Temple, on 2 February, which had by that time been accepted throughout virtually the rest of Christendom. ${ }^{7}$ Theological debates within the Jerusalem Patriarchate soon changed focus. With the Persian conquest of Jerusalem in 614 and the Arab occupation in 638, Jerusalem was no longer within the Byzantine Empire and the interlocutors in theological debates were no longer fellow Christians, but Muslims. Thus, the response of St John of Damascus in the eighth century to the problem of Iconoclasm and the veneration of images was, according to Sidney Griffith, not a direct response to the rise of Iconoclasm in Constantinople, but a reaction to theological debates brought about by the encounter between Christianity and Islam. ${ }^{8}$ Naturally, the Orthodox Patriarchate of Jerusalem sought help where it could and its patriarchs often travelled to Constantinople, Cyprus and Southern Italy, sometimes residing there in exile when the situation was too difficult in Palestine.

The difficulties of the Jerusalem Patriarchate came to a head in 1009, when Caliph al-Hākim banned Christian processions and began destroying churches. This included

\footnotetext{
${ }^{5}$ Basile-Charles Mercier, ed., La liturgie de Saint Jacques. Édition critique du texte grec avec traduction latine. Patrologia orientalis 26, no. 2 (Paris: Firmin-Didot et Cie, 1946), 166-8, 174 and 188. See also Sinai Gr. 1040 (twelfth century), ff. $7 \mathrm{v}-8 \mathrm{r}$. For the Georgian version of the Litanies, see Bernard Outtier and Stéphane Verhelst, 'La kéryxie catholique de la liturgie de Jérusalem en Géorgien (Sin. 12 et 54)', Archiv für Liturgiewissenschaft 42, nos. 1-2 (2000): 41-64, especially 55 and 57-9. For more on the Anaphora of the liturgy of St James, see André Tarby, La prière eucharistique de l'église de Jérusalem. Théologie historique 17 (Paris: Beauchesne, 1972); John D. Witvliet, 'The Anaphora of St James', in Essays on Early Eastern Eucharistic Prayers, ed. Paul F. Bradshaw (Collegeville, Minn.: The Liturgical Press, 1997), 153-72.

${ }^{6}$ For an introduction to Jerusalem's liturgy during this period, see John F. Baldovin, S. J., Liturgy in Ancient Jerusalem. Grove Liturgical Study 57 (Nottingham: Grove Books, 1989).

${ }^{7}$ Michel van Esbroeck, 'La lettre de l'empereur Justinien sur l'Annonciation et la Noël en 561', Analecta Bollandiana 86, nos. 3-4 (1968): 351-71; idem, 'Encore la lettre de Justinien. Sa date: 560 et non 561', Analecta Bollandiana 87, nos. 3-4 (1969): 442-4.

${ }^{8}$ See Sidney H. Griffith, "The Church of Jerusalem and the "Melkites": the Making of an "Arab Orthodox" Christian Identity in the World of Islam (750-1050 CE)', in Christians and Christianity in the Holy Land: From the Origins to the Latin Kingdoms, eds. Ora Limor and Guy G. Stroumsa (Turnhout: Brepols, 2006), 175-204.
} 
the Church of the Holy Sepulchre, which was demolished down to its foundations. Many Byzantine liturgists, among them the Russian pre-revolutionary scholar Alexei Dmitrievskii, whose conclusions were followed by Jesuit liturgist Miguel Arranz, have identified the destruction of the Holy Sepulchre in 1009 as a crucial turning point in Jerusalem's liturgy. ${ }^{9}$ According to this view, up to 1009, Jerusalem retained its authentic Eucharistic liturgy of St James, along with its local calendar and lectionary, but with the destruction of the Holy Sepulchre and the loss of the stational topography of the Holy City, Jerusalem's Christians adopted the liturgy of Constantinople, the capital of the Byzantine Empire, in a process known as 'liturgical Byzantinisation'. Through this process, the influence of the liturgical centre of Jerusalem upon the rest of Christendom waned and Jerusalem became a part of the Byzantine liturgical periphery, whose centre was Constantinople. Nevertheless, Dmitrievskii, whose work was interrupted in 1918 in the wake of the Russian Revolution, was never able to explain exactly how or why this change of rites occurred. Thanks to the abundant manuscript witnesses of the library of Mount Sinai, scholars are now able to say that the liturgy of Jerusalem was not 'Byzantinised' overnight. Greek, Georgian, Syrian and Arab scribes at St Sabas Lavra and on Mount Sinai had access to various types of liturgical manuscripts and themselves determined which liturgical elements would be preserved and passed on, and which would be discarded and abandoned. Thus, the process of Byzantinisation was gradual, culminating at the time of the crusades, and was effected one piece at a time, as if one were taking apart a mosaic and then trying to reassemble it. Most of these scribes were monks who had contact with the Stoudios monastery in Constantinople and, later, with the monasteries of Mount Athos. ${ }^{10}$ Likewise, the work of archaeologists and historians reveals that the Holy Sepulchre had been destroyed and rebuilt several times in the ninth and tenth centuries and that following the destruction of 1009, the Holy Sepulchre had been rebuilt within a few years and then 'restored to its original splendour' by the middle of the eleventh century, thanks to the financial support of the Byzantine emperor. ${ }^{11}$ So not only is it unlikely that the destruction of the Holy Sepulchre in 1009 would have had immediate effect on Jerusalem's liturgy, pace Dmitrievskii and those following him, but the various liturgical manuscripts copied at St Sabas Lavra or on Mount Sinai themselves point to a gradually changing liturgical tradition even before 1009 .

Ironically, at the same time that Jerusalem's Church was being liturgically Byzantinised, its Christian population was experiencing cultural Arabisation. Although Greek remained the official liturgical language of the Jerusalem Patriarchate, the vernacular of its Palestinian-born faithful changed from Syriac, or Christian Palestinian Aramaic, to Arabic around the ninth century, a change which eventually made its way fully into

\footnotetext{
9 Alexei A. Dmitrievskii, Древнбйmiе Патріарміе Типиконы Святогробскій Іерусалимскій и Великой Константинопольской Церкви. Критико-библіографическое изсльдованіе (Kiev: Типографія И.И. Горбунова, 1907), especially 77; Miguel Arranz, S.J., 'Les grandes étapes de la liturgie byzantine: Palestine - Byzance Russie. Essai d'aperçu historique', in Liturgie de l'église particulière et liturgie de l'église universelle: Conférences Saint-Serge, XXIIe semaine d'études liturgiques, Paris, 30 juin-3 juillet 1975. Bibliotheca 'Ephemerides Liturgicae', Subsidia 7 (Rome: Edizioni Liturgiche, 1976), 43-72, especially 46; Daniel Galadza, “Les grandes étapes de la liturgie byzantine” de Miguel Arranz, quarante ans après', in 60 semaines liturgiques à Saint-Serge. Bilans et perspectives nouvelles, eds. A. Lossky and G. Sekulovski (Münster: Aschendorff, 2016), 295-310.

${ }^{10}$ For a summary of liturgical Byzantinisation in Jerusalem and the importance of the Sinai 'new finds', see Daniel Galadza, 'Sources for the Study of Liturgy in Post-Byzantine Jerusalem (638-1187 CE)', Dumbarton Oaks Papers 67 (2013): 75-94; idem, Liturgy and Byzantinization in Jerusalem (Oxford: Oxford University Press, 2017).

${ }^{11}$ Robert Ousterhout, 'Rebuilding the Temple: Constantine Monomachus and the Holy Sepulchre', Journal of the Society of Architectural Historians 48, no. 1 (1989): 66-78.
} 
liturgical practice in the thirteenth century. Scholars of Arab Christianity often identify those Orthodox, or Chalcedonian, Christians in Jerusalem who spoke Arabic as a distinct subset of the Jerusalem patriarchate and refer to them as 'Melkites'. The term, however, which is derived from the Aramaic malkā or Arabic malik and means 'people of the king' or 'royalists', was first used pejoratively by non-Chalcedonians against the Orthodox Arabs and does not appear to have been used self-referentially until much later. ${ }^{12}$ Within Byzantine liturgical studies, the term 'Melkite' has been used to refer to any distinct liturgical tradition of the Orthodox Patriarchates of Antioch, Alexandria or Jerusalem, without distinction of language, whether Greek, Georgian, Syriac or Arabic. ${ }^{13}$

\section{The Orthodox Patriarchate in crusader Jerusalem}

The arrival of the crusaders in 1099 brought about a stark change for the Orthodox Patriarchate in Palestine. The main churches of the patriarchate were taken over by Latin clergy and the Greek clergy lost their primacy at the holy sites. Crusaders classified citizens of Jerusalem in three categories: first, Franks, who formed the ruling class; second, subjects who were Christian but did not follow the 'law of Rome'; and, third, subjects who were non-Christian. Had the crusaders followed Pope Urban II's initial vision of a unified Christianity in the Middle East, which envisaged the Orthodox hierarchy under the leadership of the pope of Rome, Latin-praying Christians would presumably have fallen under the jurisdiction of the local Greek-praying bishop, who would have been numbered among the 'second class' of citizens. ${ }^{14}$ Instead, the crusaders installed their own Latin bishops, while local Greek-speaking bishops remained only in episcopal sees on the periphery of the Latin Kingdom. Conflicts soon arose between the Greek and Latin clergy. In 1101, the miracle of the Holy Fire failed to take place for the clergy at the Holy Sepulchre. The Armenian chronicler Matthew of Edessa attributed this failure to the decadence of the Franks and their expulsion of the 'five faithful nations' - namely the Greeks, Latins, Syrians, Armenians and Georgians - from their respective churches and monasteries. ${ }^{15}$ Around 1107, Greek Patriarch John VIII (c.1106/7-before 1116/17) wrote two polemical treatises against the Latin practice of using unleavened bread, noting that the Latins considered the Orthodox to be 'bad' Christians. ${ }^{16}$ Patriarch John VIII is the first of the Jerusalem patriarchs to go into exile in Constantinople during the crusader period, setting a precedent for his successors until at least after 1206/7. ${ }^{17}$ In general, very little is known

\footnotetext{
${ }^{12}$ Alexander Treiger, 'Unpublished Text from the Arab Orthodox Tradition (1): On the Origin of the Term "Melkite" and On the Destruction of the Maryamiyya Cathedral in Damascus', Chronos: Revue d'Histoire de l'Université de Balamand 29 (2014): 7-37.

${ }^{13}$ See Daniel Galadza, 'Various Orthodoxies: Feasts of the Incarnation of Christ in Jerusalem in the First Christian Millennium', in Prayer and Worship in Eastern Christianities, 5th to 11th Centuries, eds. Derek Krueger and Brouria Bitton-Ashkelony (London: Routledge, 2017), 181-209 (193-4).

${ }^{14}$ For more on this relationship, see Johannes Pahlitzsch and Daniel Baraz, 'Christian Communities in the Latin Kingdom of Jerusalem (1099-1187 CE)', in Christians and Christianity in the Holy Land: From the Origins to the Latin Kingdoms, eds. O. Limor and G.G. Stroumsa (Turnhout: Brepols, 2006), 205-35 (206).

${ }^{15}$ Matthew of Edessa, 'Extraits de la chronique: II. Récit de la première croisade', in Recueil des historiens des croisades. Documents arméniens. 2 vols. (Paris: Imprimerie impériale, 1869-1906), 1: 54-5; Pahlitzsch and Baraz, 'Christian Communities in the Latin Kingdom of Jerusalem', 207.

${ }^{16}$ Pahlitzsch and Baraz, 'Christian Communities in the Latin Kingdom of Jerusalem', 207.

${ }^{17}$ Johannes Pahlitzsch, Graeci und Suriani im Palästina der Kreuzfahrerzeit. Beiträge und Quellen zur Geschichte des griechisch-orthodoxen Patriarchats von Jerusalem. Berliner Historische Studien 33 (Berlin: Duncker \& Humblot, 2001), 257.
} 
of the activity of the patriarchs of Jerusalem within the patriarchate, let alone their identity. Most information is gleaned from Constantinopolitan sources that mention the participation of Jerusalem's patriarchs in councils in the imperial capital, while few documents from Palestine even mention or note their names.

Despite this tense situation, various aspects of daily life for the local population seem to have been unaffected by the conquest of Jerusalem during the First Crusade. Legal contracts as late as 1169 still followed Islamic traditions and the multilingual and multiethnic spheres of society continued to co-exist. According to Johannes Pahlitzsch, there are approximately 150 extant Greek manuscripts either written in the scriptoria, or at one time held in the libraries, of Palestine in the twelfth and thirteenth centuries. ${ }^{18}$ Greek manuscript production continued in Palestine under Frankish rule and there was a strong cultural exchange between the churches and monasteries of Palestine and Cyprus. ${ }^{19}$ With the arrival of the crusaders, the Holy Sepulchre's Augustinian canons established a scriptorium there, along with a seminary. Few details of its activity are known with any certainty, but Hugo Buchthal speculated that it was established some time in the second quarter of the twelfth century, based on the evidence of liturgical calendars in sacramentaries and missals copied at the Holy Sepulchre that do not mention the church's rededication on 15 July 1149, on the fiftieth anniversary of the capture of Jerusalem. The scriptorium continued to produce liturgical books until 1187, when it would have been abandoned due to the retreat of the Franks from Jerusalem, and re-opened at the Cathedral of the Holy Cross in Acre a few years later. ${ }^{20}$ Two noted examples from the Jerusalem scriptorium are Paris, Bibliothèque nationale de France, MS Lat. 276, and Rome, Biblioteca Apostolica Vaticana, MS Vat. Lat. 5974, both of which reproduce Byzantine illuminations, most likely modelled on Biblioteca Apostolica Vaticana, MS Vat. Gr. 756 (eleventh century), reflecting a 'Byzantine-crusader alliance' in manuscript workshops and mosaic ateliers. ${ }^{21}$ Another hagiopolite example of Western and Byzantine fusion is the so-called 'Psalter of Queen Melisende', London, British Library, MS Egerton 1139, whose calendar commemorations suggest it was copied at some point between 1131 and 1143, most likely in 1134 or $1135 .^{22}$

\section{Cathedral liturgy: the 'Anastasis Typikon', Hagios Stavros Gr. 43 (A.D. 1122)}

The first of the two Greek manuscripts that are the focus this paper, codex Hagios Stavros Gr. 43, was copied at the Holy Sepulchre in 1122, one decade before the Psalter of Queen Melisende. The manuscript, referred to as the Anastasis Typikon in Byzantine liturgical scholarship, is still housed at the Library of the Jerusalem Patriarchate, although today several folios are found at the Russian National Library in St Petersburg under the

\footnotetext{
${ }^{18}$ Pahlitzsch, Graeci und Suriani im Palästina, 330-53; Pahlitzsch and Baraz, 'Christian Communities in the Latin Kingdom of Jerusalem', 211.

${ }^{19}$ Pahlitzsch and Baraz, 'Christian Communities in the Latin Kingdom of Jerusalem', 211.

${ }^{20}$ Hugo Buchthal, Miniature Painting in the Latin Kingdom of Jerusalem (Oxford: Clarendon Press, 1957), $\mathrm{xxx}-\mathrm{xxxi}$.

${ }^{21}$ Jaroslav Folda, Crusader Art: the Art of the Crusaders in the Holy Land, 1099-1291 (Aldershot: Lund Humphries, 2008), 50-6 and 80.

${ }^{22}$ Folda, Crusader Art, 32-3; Jaroslav Folda, '259. Queen Melisende's Psalter', in The Glory of Byzantium: Art and Culture of the Middle Byzantine Era, A.D. 843-1261, eds. Helen C. Evans and William D. Wixom (New York: The Metropolitan Museum of Art, 1997), 392-4. For the contents of the manuscript, see Buchthal, Miniature Painting in the Latin Kingdom of Jerusalem, 139-40 (Appendix III).
} 
shelfmark MS Gr. 359. ${ }^{23}$ Its contents consist of a liturgical book of the Church of the Anastasis in Jerusalem for services during Holy Week, Easter and the week after Easter, also known as Bright Week. Because the manuscript is acephalous, presumably once beginning with the now-missing services of Lazarus Saturday and ending with the service for the Saturday after Easter, it bears no title. However, its lengthy colophon indicates that the

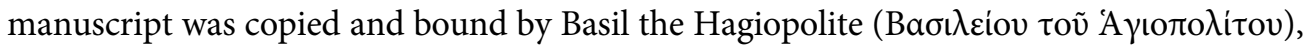

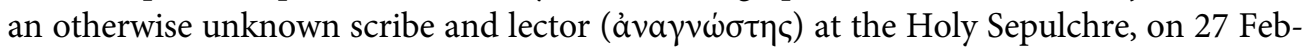
ruary 1122, at the behest of George, archon and judge of the Holy City, as well as sakellios and great skeuophylax of the Church of the Anastasis. ${ }^{24}$ The colophon also specifies that the liturgical practices described in the manuscript are a faithful copy from an older scroll, also from the Holy Sepulchre. ${ }^{25}$ This colophon confirms that this manuscript is an unparalleled witness of the cathedral liturgy in crusader Jerusalem, of equal value to Egeria's travel diaries or the early Armenian and Georgian translations of the Jerusalem lectionary in understanding the development the Holy City's liturgy. ${ }^{26}$

Nevertheless, numerous authors have questioned the manuscript's dating to a period after 1099, during Frankish rule. ${ }^{27}$ Could this text have been made and used for Greek liturgical services in 1122, when the Holy Sepulchre was in the hands of Latin clergy? If not, would it have been copied simply as a historical artefact reflecting older liturgical practices?

Dmitrievskii demonstrated that many of the basic elements of the Anastasis Typikon reflect Egeria's accounts. ${ }^{28}$ For example, groups of monks are central to the continuity of the services at the Holy Sepulchre. ${ }^{29}$ Liturgical history reveals two kinds of monastic rites: the communal and/or private services obligatory for monks every day, and the less frequent communal services celebrated by the whole community. These were

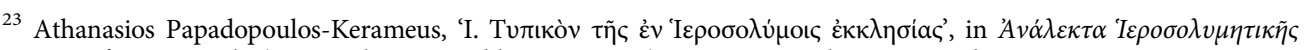
$\Sigma \tau \alpha \chi v o \lambda$ oyi $\alpha$ c. 5 vols. (St Petersburg: Kirschbaum, 1891-8), 2: 1-254. See also Dmitrievskii, Древнъйmiе Патріариіе Типиконы, and Gabriel Bertonière, The Historical Development of the Easter Vigil and Related Services in the Greek Church. Orientalia Christiana Analecta 193 (Rome: Pontifical Oriental Institute, 1972), 12-18 and especially 16-17, for discussions of this manuscript. For the St Petersburg folia, see E.E. Granstrem, 'Каталог греческих рукописей ленинградских хранилищ, 4: Рукописи ХІІ века', Византийский Временник 23 (1963): 171.

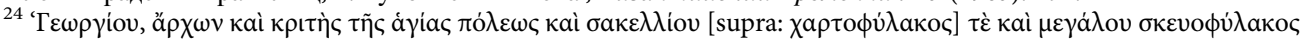

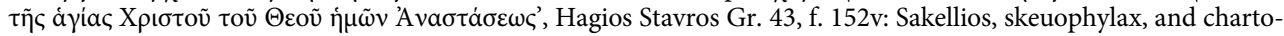
phylax are all titles of distinguished administrative offices charged with preservation and administration of documents and property. See Alexander Kazhdan and Paul Magdalino 'Sakellarios', 3: 1828-9; idem, 'Sakellion', 3: 1829-30; R.J. Macrides, 'Chartophylax', 1: 414-15; Paul Magdalino and Alice-Mary Talbot, 'Skeuophylax', 3 : 1909-10, in The Oxford Dictionary of Byzantium, eds. Alexander P. Kazhdan and others. 3 vols. (New York: Oxford University Press, 1991).

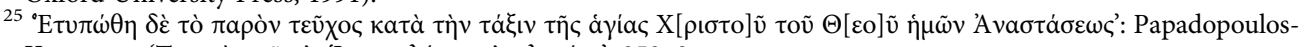

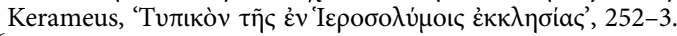

${ }^{26}$ See Athanase (Charles) Renoux, ed. Le codex arménien Jérusalem 121, vol. 2, Édition comparée du texte et de deux autres manuscrits. Patrologia orientalis 36, no. 2 (Turnhout: Brepols, 1971); Michel Tarchnischvili, ed., Le grand lectionnaire de l'église de Jérusalem (Ve-VIIIe siècle). CSCO 188-9 and 204-5 (Louvain: Secrétariat du CSCO, 19591960). The original Greek lectionary of Jerusalem from the fourth through to the eighth century has been lost, but these Armenian and Georgian translations have been preserved. For more on the original Greek lectionary manuscripts, see Daniel Galadza, 'The Jerusalem Lectionary and the Byzantine Rite', in Rites and Rituals of the Christian East. Proceedings of the Fourth International Congress of the Society of Oriental Liturgy, Lebanon, 10-15 July 2012, eds. Bert Groen and others. Eastern Christian Studies 22 (Leuven: Peeters, 2014), 181-99.

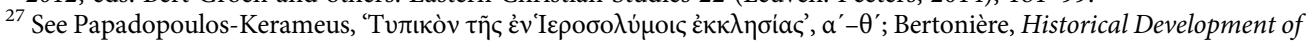
the Easter Vigil, 12-18; Sebastià Janeras, Le Vendredi-Saint dans la tradition liturgique byzantine. Structure et histoire de ses offices. Studia Anselmiana 99/Analecta Liturgica 13 (Rome: Pontificio Ateneo S. Anselmo, 1988), 40; John F. Baldovin, S.J., The Urban Character of Christian Worship: the Origins, Development, and Meaning of Stational Liturgy, Orientalia Christiana Analecta 228 (Rome: Pontifical Oriental Institute, 1987), 80-2.

${ }^{28}$ Dmitrievskii, Древнъйшіе Патріариіе Типиконь, 66-70.

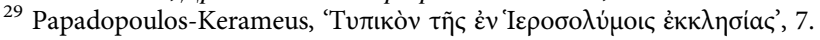


served side by side in Jerusalem, with monastic influence eventually causing the expansion of the cathedral cursus from a daily morning and evening service to a multiplicity of daily offices observed even by the laity. ${ }^{30}$ One such monastic group in the Anastasis Typikon,

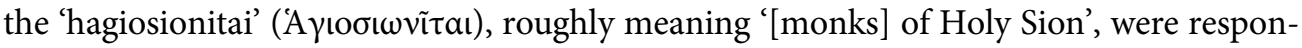

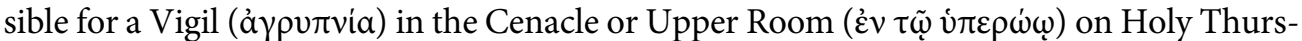

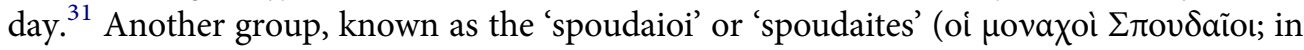
Georgian: lз3m6coogm6o, spondielni), meaning 'zealous ones', also served at the Anastasis and are identified as the group responsible for the beginning of the Vigil on the eves of Palm Sunday ${ }^{32}$ and Holy Saturday, ${ }^{33}$ had their own order of services, ${ }^{34}$ and lived at the

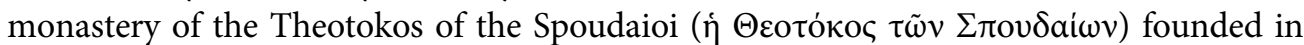
Jerusalem near the Anastasis by Patriarch Elias (reigned 494-516) in $494 .{ }^{35}$ Dmitrievskii believed they would serve uninterrupted services at the holy sites and would fill in the times until the patriarch arrived, ${ }^{36}$ in a manner similar to that of the 'monazontes' and 'parthenae' observed by Egeria. ${ }^{37}$ Because the Anastasis Typikon only contains the text of the liturgical services for two weeks of the year, it is impossible to say if this group of monks would have held such duties during the remainder of the liturgical seasons. According to Sophrone Pétridès, 'spoudaioi' are also mentioned in Constantinople and

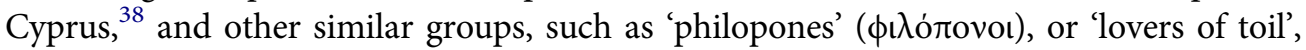
were found in Alexandria, Beirut and Antioch, the most famous member of such a group being the sixth-century Alexandrian philosopher, John Philoponos. ${ }^{39}$ It is not clear, however, if these terms are ever used in a liturgical context. The examples provided by Pétridès lead the reader to believe they do not in fact refer to a coherent, liturgical group, whether monastic or lay, or a distinct monastic order, as one could find in the West. Thus, their presence in Jerusalem as late as the twelfth century - if we are to trust the references to them in the Anastasis Typikon - is significant.

There are still further aspects of continuity in the Anastasis Typikon. The celebration of the Liturgy of St James, the principal hagiopolite Eucharistic liturgy, is explicitly prescribed on Palm Sunday, Holy Thursday, Holy Saturday and Easter. Despite the presence of the Liturgy of St James, the hymnography associated with this liturgy is a mix of local hagiopolite hymnography closely connected to the Jerusalem lectionary and antiphons and hymns adopted from Constantinople. ${ }^{40}$

\footnotetext{
${ }^{30}$ Anton Baumstark, Comparative Liturgy, ed. Bernard Botte, trans. F.L. Cross. Rev. edn. (Westminster, Md.: Newman Press, 1958), 111-13; Robert F. Taft, S.J., The Liturgy of the Hours in East and West: the Origins of the Divine Office and Its Meaning for Today. 2nd rev. edn. (Collegeville, Minn.: The Liturgical Press, 1993), 76-80.

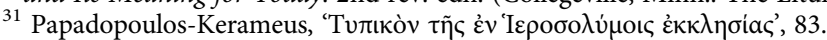

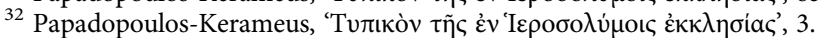

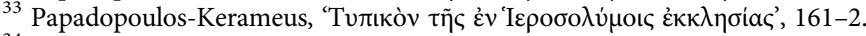

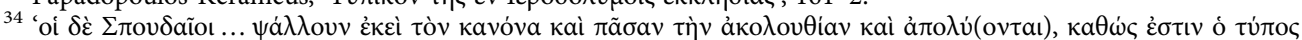

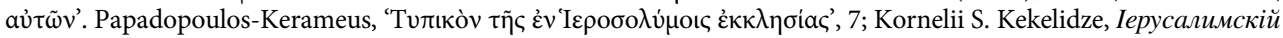
Канонарь VII въка (Грузинская версія) (Tbilisi: Лосаберидзе, 1912), 265-7.

${ }^{35}$ See Chapter 31 of the Life of Sabas, in Kyrillos von Skythopolis, ed. Eduard Schwartz. Texte und Untersuchungen 49, no. 2 (Leipzig: Hinrichs, 1939), 116 (lines 4-8). See also Le grand lectionnaire de l'église de Jérusalem, \$1140, for the feast of the dedication of the Church of the Theotokos of the Spoudaioi on 11 August.

${ }^{36}$ Dmitrievskii, Древньйміе Патріариіе Типиконы, 111-13.

${ }^{37}$ Égérie, Journal de voyage, 234-6 (24: 1) and 248-50 (25: 6).

38 Sophrone Pétridès, 'Le monstère des Spoudæi à Jérusalem et les Spoudæi de Constantinople', Échos d'Orient 4 (1900-1): 225-28; idem, 'Spoudæi et Philopones', Échos d'Orient 7 (1904): 341-8.

${ }^{39}$ Barry Baldwin and Alice-Mary Talbot, 'Philoponos, John', in Oxford Dictionary of Byzantium, eds. Kazhdan and others, 3: 1657.

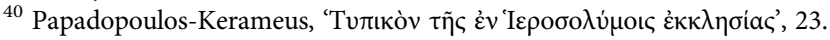


The stational character of the services is preserved, with processions to and from the cross at Golgotha during vigil ${ }^{41}$ and synaxes at the Mount of Olives, Gethsemane, the Mar-

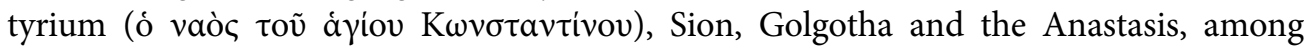
others. ${ }^{42}$ The multilingualism of Jerusalem's liturgy observed by Egeria in the fourth century is also preserved in the Anastasis Typikon during the Matins of Pascha for the reading of the Easter Homily attributed to St John Chrysostom:

And immediately the patriarch stands on the synthronon [semi-circular benches for clergy in the apse] and the archdeacon says 'Let us attend!' and immediately begins to read this in a loud voice: 'Of our father among the saints, John Chrysostom, a homily for holy Pascha', (which begins) 'If anyone is pious and God-loving' etc. Then the second of the deacons translates the homily into the Arabic language, so that those who do not know how to read Greek may be comforted and that all the people may have joy, exultation and merriment - both the small and the great. ${ }^{43}$

However, by the twelfth century Arabic had replaced the 'Syrian' language ('siriste'). ${ }^{44}$

Despite these similarities with Jerusalem's late antique liturgical practice, much of the hymnography and the structure of the offices are what one would expect of the Byzantine rite of the twelfth century. This mix of Jerusalem and Constantinople rites is evidenced even further by the fact that the text of the Anastasis Typikon references both the order

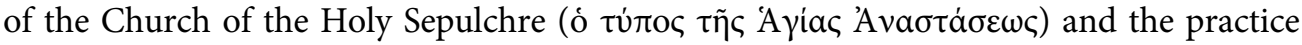
of Constantinople ( $\tau \tilde{\eta} \varsigma \mathrm{P} \omega \mu \alpha v i \varsigma_{\varsigma} \tau \dot{\alpha} \xi \iota \varsigma$ ), even at times making reference to alternate rubrics for Constantinopolitan scriptural pericopes. For example, for the celebration of the Liturgy of St James on Holy Thursday, the copyist gives two possible Gospel pericopes: the first, Mark 14:12-26, relating only the events of the Last Supper, according to the 'typos' of the Holy Sepulchre; and the second, Matthew 26:1-27: 2, recounting the Last Supper, Christ's betrayal by Judas, Judas hanging himself and Peter's denial, according to the 'Roman [i.e. Byzantine] order'. ${ }^{45}$

The possibility of continuity between the liturgy of Jerusalem witnessed by Egeria and the liturgy transcribed in the Anastasis Typikon, however, was strongly questioned by Alexei Dmitrievskii. As mentioned above, Dmitrievskii claimed that the destruction of various holy sites, especially the destruction of the Anastasis in 1009, would have made it impossible for many of the services to take place as they were described ${ }^{46}$ and insisted that the manuscript was a copy of a tenth-century manuscript based on a reference to

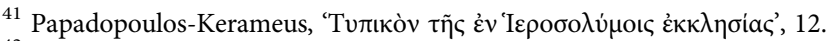

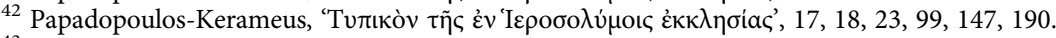

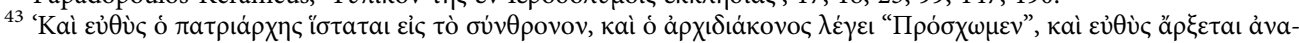

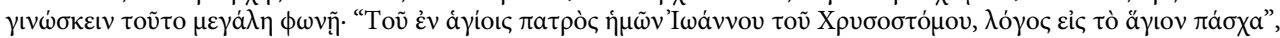

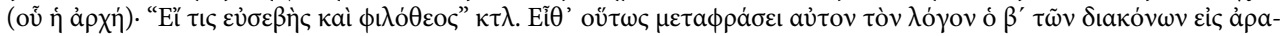

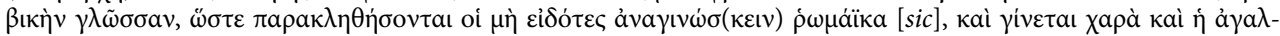

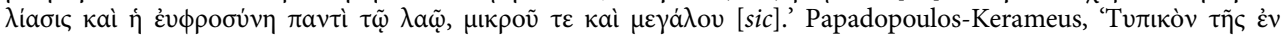

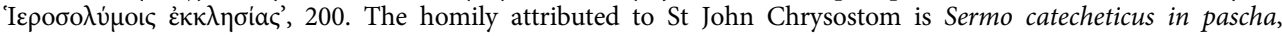
CPG, 4605; J.-P. Migne, ed., Doctores scriptoresque ecclesiae graecae a S. Barnaba ad Bessarionem. PG 59 (Paris: J.-P. Migne, 1862), cols. 721-4; Arabic version: Sinai Ar. 455 (twelfth century), ff. 90-2; BnF, MS ar. 262 (fifteenth century), f. 189v (no. 17). See Gérard Troupeau, Catalogue des manuscrits arabes. Première partie: manuscrits chrétiens, vol. 1 (Paris: Bibliothèque Nationale, 1972), 228.

${ }^{44}$ The language Egeria refers to by the term 'siriste' may be Christian Palestinian Aramaic and not Syriac. See Égérie, Journal de voyage, 314 (47: 3-4); Scott F. Johnson, Languages and Cultures of Eastern Christianity: Greek. The Worlds of Eastern Christianity, 300-1500: 6 (Burlington: Ashgate, 2015), 4-7.

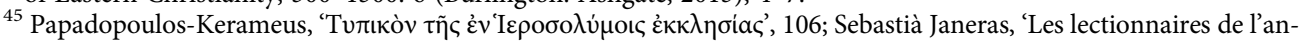
cienne liturgie de Jérusalem', Collectanea Christiana Orientalia 2 (2005): 71-92 (89).

${ }^{46}$ Dmitrievskij, Древнъйміе Патріариіе Типиконь, 74-83.
} 
Patriarch Nicholas of Jerusalem, mentioned in the prayer for those bringing offerings on Palm Sunday, whom Dmitrievskii claimed reigned from 932 to 945 or $947 .{ }^{47}$ For Dmitrievskii, all these factors pointed to a terminus ante quem of 1009, the latest accepted date of the destruction of the Anastasis by al-Hākim, and a terminus post quem of 886, based on the names of hymnographers mentioned in the text. Thus, Dmitrievskii thought that the monk Basil copied the text for posterity's sake and intended it as a historic artefact.

More recent studies of architectural history and prosopography have shown Dmitrievskii's arguments are based on incomplete or outdated information. The Holy Sepulchre complex was rebuilt and rededicated by 1048, providing the necessary liturgical space for the services of the Anastasis Typikon. ${ }^{48}$ Recent studies of Byzantine prosopography shed more light on the identity of Patriarch Nicholas and place his reign between February 1122, when Hagios Stavros Gr. 43 was copied, and January 1156, when he is mentioned at a synod in Constantinople. ${ }^{49}$ This evidence should encourage liturgical scholars to reconsider the Anastasis Typikon as a twelfth-century witness to the late stages of liturgical Byzantinisation in Jerusalem during the First Crusader Latin Kingdom. The manuscript's transitional character, evidenced by its scribe's familiarity with the practice of both Jeru-

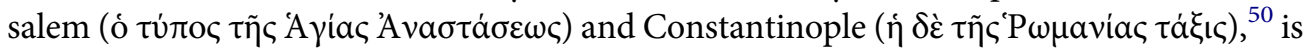
a sign of Basil's work as a redactor reporting liturgical changes taking effect or conflicts in liturgical practice. Ignoring such scribal notes underestimates Basil the Hagiopolite's role as a redactor. ${ }^{51}$ This all suggests that the manuscript is indeed a twelfth-century witness of how the important figures mentioned in the colophon would have celebrated Holy Week and Easter at the Anastasis in 1122 if this were possible. ${ }^{52}$

Whether this was possible is another question. It is unclear if Patriarch Nicholas was present in Jerusalem for Easter in 1122 or at any point during his reign. ${ }^{53}$ More problematic is the role of Greek clergy at the Holy Sepulchre during the Latin Kingdom of Jerusalem. The pilgrimage account of the Abbot Daniel dated to $c .1104-6$ recounts that the descent of the Holy Fire at the Anastasis on Holy Saturday took place with both Greek and Latin clergy present. After leaving the metochion (a small monastic establishment or urban base) of the Mar Sabas Lavra near David's Tower with the abbot and monks of St Sabas who formed part of King Baldwin's retinue, Daniel describes the event as follows:

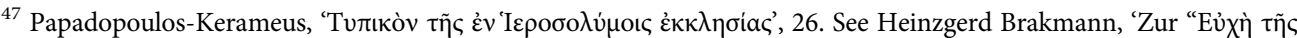
картофоріас" in der melchitischen Markos-Liturgie’, Ephemerides Liturgicae 98 (1984): 75-80; Dmitrievskii, Древнбйшіе Патріариіе Типиконы, 101, 109. Bertonière, Easter Vigil, 13-14, follows Dmitrievskii.

${ }^{48}$ Ousterhout, 'Rebuilding the Temple: Constantine Monomachus and the Holy Sepulchre', 71-2.

49 The Prosopographie der mittelbyzantinischen Zeit identifies 267 Nicholases known to have lived between 867 and 1025 , but none of them matches Dmitrievskii's proposed patriarch of Jerusalem. The only figures that bear some resemblance are Patriarch Nikolaos I Mystikos of Constantinople (d. 925, \#25885), who ruled twice in Constantinople, Patriarch Nikolaos II Chrysoberges of Constantinople (d. 992, \#26019), who is commemorated in diptychs in Messina Gr. 177, and Patriarch Nikolaos II of Antioch (d. 1030, \#26124). See F. Winkelmann and others, eds., Prosopographie der mittelbyzantinischen Zeit. 2. Abteilung (867-1025). 8 vols. (Berlin: De Gruyter, 2013), \#25885\#26152. Copyists named Basil are known from the period between 867 and 1025, but none of them matches the copyist of the Anastasis Typikon. See the index in Prosopographie der mittelbyzantinischen Zeit. 2. Abteilung (867-1025), 8: 391. Fedalto shows some uncertainty about the period from 932 to 945: Giorgio Fedalto, 'Liste vescovili del patriarcato di Gerusalemme. I: Gerusalemme e Palestina prima', Orientalia Christiana Periodica Roma

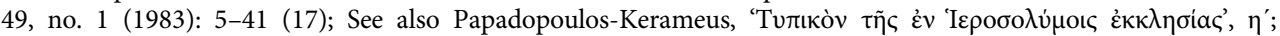
Angelo Mai, Spicilegium Romanum, vol. 10, Synodus Constantinopolitana (Rome: Typis Collegii Urbani, 1844 ), 16.

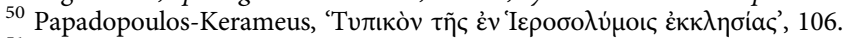

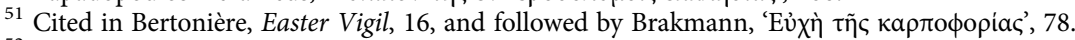

${ }^{52}$ See Bertonière, Easter Vigil, 16-17.

${ }^{53}$ For more on Patriarch Nicholas, see Pahlitzsch, Graeci und Suriani im Palästina, 138-40.
} 
When it was the eighth hour of the day [2 p.m.], the Orthodox priests, the monks [черноризци, literally 'those in black robes'], and all the spiritual men [вси духовніи мужи] began to sing Vespers above the Sepulchre. There were many hermits present. The Latins at the great altar began to squeal in their own manner [начаша верещати свойскы]. While they were singing I stood there, attentively looking towards the doors of the Sepulchre. When they began reading the Old Testament prophecies of Holy Saturday [начяша чести пареміи тоя суботы великіа], the bishop came down from the great altar with the deacon during the first Old Testament prophecies and came to the doors of the Sepulchre, looked into the Sepulchre through the grille of its doors [сквозђ крестець дверей тъхъ], did not see light in the Sepulchre, and returned to his place. When the sixth Old Testament prophecy was read, the same bishop came to the doors of the Sepulchre and did not see anything. ${ }^{54}$

Once the Holy Fire did appear, the bishop came to the Sepulchre with four deacons, took King Baldwin's candle, entered the Sepulchre, lit the candle and returned it to the king, from whom all the others present lit their candle. Once everyone had lit their candles, they went home to light their lamps and finished singing Vespers at home (канчивають пьніе вечернее дома), leaving the priests alone at the Holy Sepulchre to finish Vespers there (въ велицьй церкви, у Гроба Господня, сами попове едини, безъ людій, канчивають пьніе вечернее). ${ }^{55}$ Daniel's reference to the Greek vigil service and its Old Testament readings gives the impression of two parallel and simultaneous Greek and Latin liturgical services, rather than a single service, while all were waiting for the Holy Fire. ${ }^{56}$ As Christopher MacEvitt notes, no Greek bishop was present at the Holy Sepulchre, and the abbot and monks of St Sabas Lavra were considered part of the royal retinue - and not the ecclesiastical hierarchy - due to their connections to Queen Melisende and the royal court. ${ }^{57}$

\section{Monastic liturgy: the Sabaite Typikon, Sinai Gr. 1096 (twelfth century)}

As becomes clear from the witnesses of services at the Holy Sepulchre, the role of monks in Jerusalem's liturgical life was crucial in hagiopolite liturgy during the crusader period. At its peak in the fifth and sixth centuries Palestinian monasticism counted at least 64 monasteries, and monks actively participated in services at the Holy Sepulchre. ${ }^{58}$ The most

\footnotetext{
${ }^{54}$ M.A. Venevitinov, ed., Житье и хожденье Даниила руськыя земли игумена, 1106-1107 г2. Православный Палестинскій Сборникъ 3 (St Petersburg: Типографія В.Ө. Киршбаума, 1885), 133; G.M. Prokhorova, ed. and trans., 'Хождение игумена Даниила', in Библиотека литературы Древней Руси, vol. 4, XII век, eds. D.S. Likhacheva and others (Moscow: Художественная литература, 1980), 110; John Wilkinson and others, eds., Jerusalem Pilgrimage, 1099-1185 (Farnham: Ashgate, 2010), 168-9. I have revised Wilkinson's English translation based on the Slavonic text.

${ }^{55}$ Venevitinov, Житье и хожденье Даниила, 135-6; Prokhorova, ed., 'Хождение игумена Даниила', 112.

${ }^{56}$ For an analysis of the liturgical elements here, see Bertonière, Easter Vigil, 48-58.

${ }^{57}$ Christopher MacEvitt, The Crusades and the Christian World of the East: Rough Tolerance (Philadelphia: University of Pennsylvania Press, 2008), 120-2.

${ }^{58}$ The best surveys of Palestinian monasticism are Derwas J. Chitty, The Desert a City: an Introduction to the Study of Egyptian and Palestinian Monasticism under the Christian Empire (Oxford: Basil Blackwell, 1966); Yizhar Hirschfeld, The Judean Desert Monasteries in the Byzantine Period (New Haven: Yale University Press, 1992); Joseph Patrich, Sabas, Leader of Palestinian Monasticism: a Comparative Study in Eastern Monasticism, Fourth to Seventh Centuries (Washington, DC: Dumbarton Oaks Research Library and Collection, 1995). For a list of these monasteries, see Siméon Vailhé, 'Répertoire alphabétique des monastères de Palestine', Revue de l'Orient Chrétien 4 (1899): 512-42; idem, 'Répertoire alphabétique des monastères de Palestine', Revue de l'Orient Chrétien 5 (1900): 19-48 and 272-92. For an updated list, including recent archaeological discoveries, see Yizhar Hirschfeld, 'List of the Byzantine Monasteries in the Judean Desert', in Christian Archaeology in the Holy Land: New Discoveries. Essays in Honour of Virgilio C. Corbo, OFM, eds. G.C. Bottini, L. De Segni and E. Alliata. Studium Biblicum Franciscanum, collectio maior 40 (Jerusalem: Franciscan Printing Press, 1990), 1-90.
} 
prominent Palestinian monastery, the Lavra of St Sabas, was initially established in 483 by St Sabas the Sanctified (439-532). ${ }^{59}$ The manuscript Sinai Gr. 1096 is one of the most significant manuscripts associated with that monastery since it contains a collection of documents related to the Lavra's daily life, including liturgical, administrative and disciplinary regulations. Although the manuscript does not contain a colophon, its script has been dated to the twelfth century and its frequent references to the specific topography of the Lavra of St Sabas leaves no doubt this manuscript describes the liturgy of that monastery. Dmitrievskii described the manuscript but its text has never fully been edited, most likely because it was not photographed among the microfilms of the Sinai expedition conducted by the Library of Congress in $1950 .{ }^{60}$ The title of this codex is 'Typikon of the Ecclesiastical Service in Jerusalem of the Holy Lavra of Our Venerable and God-bearing Father Sabas'. ${ }^{61}$ The manuscript's 193 folios begin with a description of a liturgical

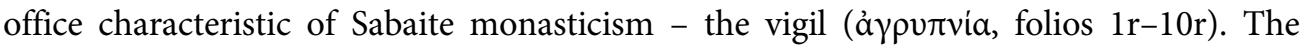
general practice of lavriote monasticism was for the monks to pray privately in their cells scattered in the wilderness surrounding the monastery and to gather for common services in the monastery's main church on Saturdays and Sundays, giving rise to the Sabaite

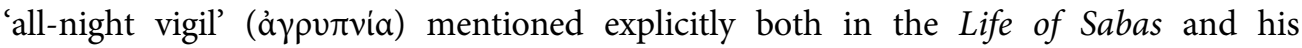
'Testament'. 62

The common language of the monastery was Greek, but Syrian and Georgian monks were also integral members of the community. Although the primary liturgical language of most Palestinian monasteries was Greek, the same multilingualism that Egeria witnessed in the fourth century is also reflected here. The Life of St Sabas states that Armenian

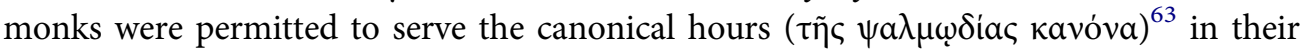
own language ( $\tau \tilde{\eta} \tau \tilde{\omega} \nu$ 'A $\rho \mu \varepsilon v i \omega v \delta\llcorner\alpha \lambda \dot{\varepsilon} \kappa \tau \omega)$, but were to join the Greeks for the Divine Liturgy. ${ }^{64}$ This practice is also mentioned in the 'Testament of St Sabas' from Sinai Gr. 1096. The description of the liturgical services within the monastery is as follows:

Nor shall it be permitted that the Iberians [Georgians], or the Syrians, or the Franks celebrate a complete liturgy in their churches. Let them instead gather over there, and sing the canonical hours and Typika in their own language, and read the Epistle and the Gospel as well,

\footnotetext{
59 Patrich, Sabas, 57-66. See also Siméon Vailhé, 'Le monastère de Saint-Sabas', Échos d'Orient 2 (1898-9): 332-41; idem, 'Le monastère de Saint-Sabas', Échos d'Orient 3 (1899-1900): 18-28 and 168-77.

${ }^{60}$ Dmitrievskii's description has been compared with photographs of the manuscript taken in July 2012. The total number of extant folios observed in July 2012 was 193, as opposed to 185 described by Dmitrievskii. See Dmitrievskii, Onисанie, 3: 20-65; Clark, Checklist of Manuscripts in St Catherine's Monastery, Mount Sinai, 11.

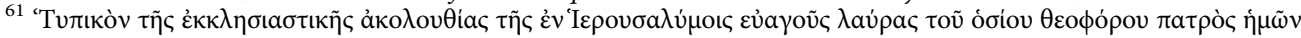
$\Sigma \alpha \dot{\beta} \beta \alpha^{\prime}$ : Dmitrievskii, Onucauie, 3: 20. For a description of another liturgical Typikon, Codex HAAB Q 740 (thirteenth-fourteenth century) of the Duchess Anna Amalia Library in Weimar, see Diego R. Fittipaldi, 'The Typicon of Mâr Saba in the XIII Century or What and When to Read in the Monastic Byzantine Liturgy', Temas Medievales 23 (2015): 89-113.

62 Sinai Gr. 1096, f. 148r; Alexei A. Dmitrievskii, Описаніе литургическихъ рукописей, хранящихся въ библіотекахъ православнаго востока, vol. 1, Тvлıка́ (Kiev: Типографія Г.Т. Корчакъ-Новицкаго, 1895), 222-3; Gianfranco Fiaccadori, '42. Sabas: Founder's Typikon of the Sabas Monastery near Jerusalem', in Byzantine Monastic Foundation Documents, eds. John Thomas and Angela Constantinides Hero. 5 vols. (Washington, DC: Dumbarton Oaks Research Library, 2000), 4: 1316.

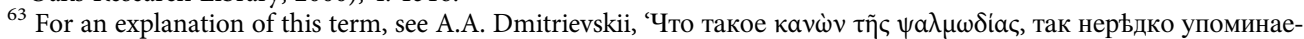
мый въ жизнеописаніи препод. Саввы Освященнаго?', Руководство для сельскихъ пастырей 38 (1889): 69-73.

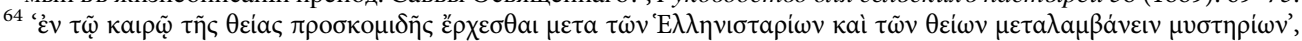

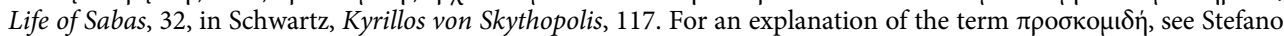

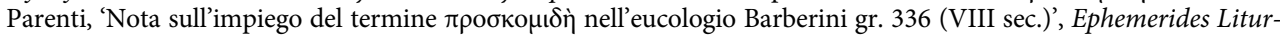
gicae 103 (1989): 406-17; Pavlos Koumarianos, 'Prothesis and Proskomide: a Clarification of Liturgical Terminology', Greek Orthodox Theological Review 52, nos. 1-4 (2007): 63-102, especially 68-72.
} 
and then go to the Great Church and take part in the divine, undefiled, and life-giving sacraments together with the whole brotherhood. ${ }^{65}$

By all accounts, the Eucharistic liturgy of the Lavra's monastic brotherhood would have been the Liturgy of St James, but Sinai Gr. 1096 makes no mention of it, and the regulations concerning the celebration of the Divine Liturgy only prescribe the Liturgies of St John Chrysostom or St Basil the Great - completely in keeping with Constantinopolitan Byzantine practice. The reference to 'Franks' (oi $\Phi \rho \alpha \dot{\gamma} \gamma o$ ), believed to be a later interpolation into the original text, confirms that Frankish monks were present as St Sabas Lavra as permanent residents, as they had been in other parts of Palestine, such as the Mount of Olives, for centuries before the First Crusade. ${ }^{66}$ 'Syrians', referring to speakers of Syriac, Christian Palestinian Aramaic and Arabic, also had a prominent place in the daily affairs of the Lavra of St Sabas and were responsible for the monastery's finances since they were 'more efficient and practical in their native country'. ${ }^{67}$ Nevertheless, Syrians were never permitted to be abbots in these monasteries and, thus, Syriac never held liturgical primacy within the multilingual monastic communities of Palestine or the Jerusalem cathedral. Georgians had a significant presence in Palestine from the fifth century, and St Sabas Lavra was the focal point of Georgian scribal activity outside the Caucasus until 980, when it was transferred to Sinai. ${ }^{68}$

Because Sinai Gr. 1096 is, in effect, the oldest extant Greek manuscript of the Sabaite Typikon, it is difficult to know exactly what the liturgical practices of the Sabas Lavra were before the time of this manuscript, and thus before Frankish presence. For this reason, it is difficult to explain why the liturgical calendar of Sinai Gr. 1096 shows few similarities to other contemporaneous hagiopolite liturgical calendars. For example, the liturgical year proceeds from 1 September until 31 August, ${ }^{69}$ unlike standard liturgical calendars in Jerusalem that began on 25 December or 25 March. Compared with hagiopolite calendars, such as the Armenian and Georgian lectionaries mentioned above, the Sabaite Typikon of Sinai Gr. 1096 is virtually unrecognisable as a calendar originating in the Jerusalem patriarchate. The local saints of Jerusalem's calendar are frequently exchanged for numerous monastic Sabaite saints, and even those local saints that were part of Jerusalem's original sanctoral are shifted in Sinai Gr. 1096 to the date of their commemoration in Constantinople. ${ }^{70}$ St Sabas features prominently in the daily office and

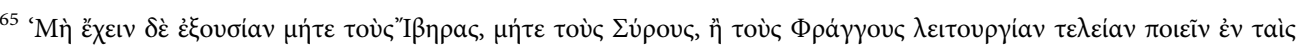

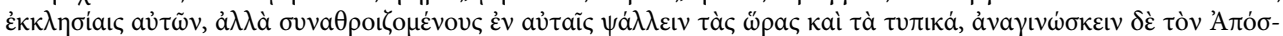

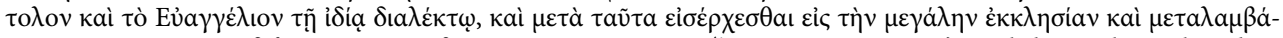

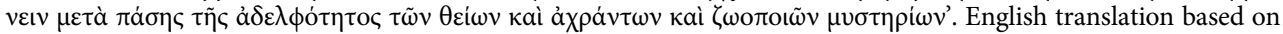
Gianfranco Fiaccadori, '42. Sabas: Founder's Typikon of the Sabas Monastery Near Jerusalem', in Byzantine Monastic Foundation Documents, eds. Thomas and Constantinides Hero, 4: 1316.

${ }^{66}$ Michael McCormick, Charlemagne's Survey of the Holy Land: Wealth, Personnel, and Buildings of a Mediterranean Church between Antiquity and the Middle Ages (Washington, DC: Dumbarton Oaks, 2011), $206-7$.

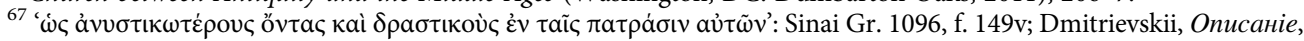
1: 224; Fiaccadori, 'Sabas: Founder's Typikon', in Byzantine Monastic Foundation Documents, eds. Thomas and Constantinides Hero, 4: 1317. The earliest known Syriac liturgical Typika from Mar Sabas Lavra are manuscripts Sinai Syr. 129 (A.D. 1255) and Sinai Syr. 136 (thirteenth century), dated slightly later than Sinai Gr. 1096.

${ }^{68}$ Michael Tarchnishvili, Geschichte der kirchlichen georgischen Literatur. Studi e Testi 185 (Vatican City: Biblioteca Apostolica Vaticana, 1955), 62-3 and 69.

${ }^{69}$ Sinai Gr. 1096, ff. 25r-129r; Dmitrievskii, Описанie, 3: 28-55. Although the calendar includes commemorations for every day of the year, commemorations from 21 to 24 March are missing from the manuscript.

${ }^{70}$ For an overview of hagiopolite liturgical calendars and their Byzantinisation, i.e. their evolution under the influence of Constantinopolitan liturgical practice, see Daniel Galadza, 'Liturgical Byzantinization in Jerusalem: Al-Bīrūnī's Melkite Calendar in Context', Bollettino della Badia Greca di Grottaferrata, 3rd series, 7 (2010): 69-85.
} 
hymns dedicated to his memory are sung as part of the ordinary. ${ }^{71}$ His veneration is so great that his feast on 5 December even includes an octave, something otherwise unknown beyond feasts of Christ or the Theotokos. ${ }^{72}$ This particular veneration is accompanied by frequent processions to the tomb of St Sabas and other specific chapels of the Lavra during the vigil, at the end of Vespers as well as Orthros, approximately 66 times a year. ${ }^{73}$ The stations within the territory of the monastery mentioned in Sinai Gr. 1096 include three churches and the tomb of St Sabas: the main church of the monastery dedicated to the Annunciation, the 'God-built' cave-church dedicated to the Theo-

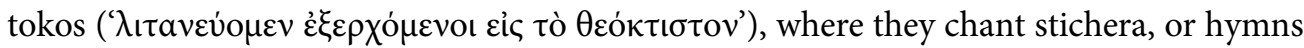

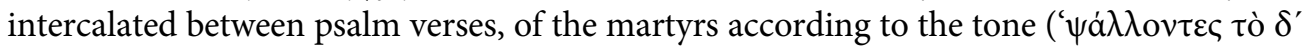

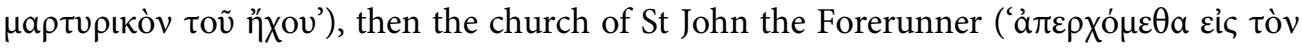

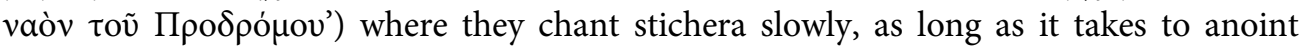

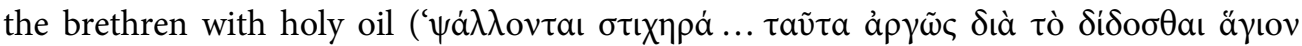

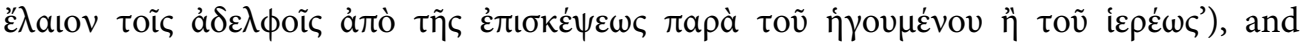
finally to the tomb of St Sabas, where the priest recites more litanies ('

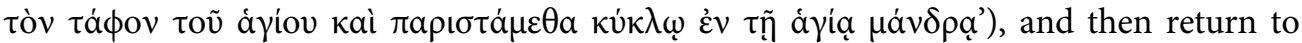

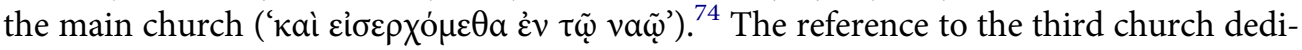
cated to the Forerunner is significant, since this church is unknown today. It was, however, known to the pilgrim Abbot Daniel, who describes the Lavra of St Sabas as follows:

There are three churches here ... and between the three churches is the tomb of St Saba, about four fathoms $[7.3 \mathrm{~m}]$ from the great church, and there is a beautifully executed chapel over the tomb. ${ }^{75}$

The remainder of the manuscript contains the service for the washing of feet on Holy

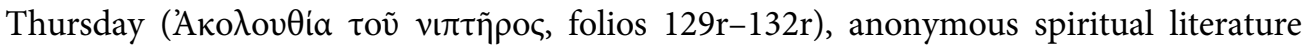

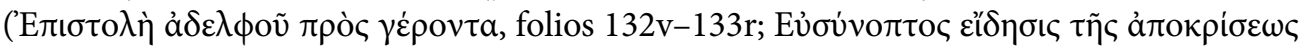
$\pi \varepsilon \rho \grave{i} \tau \tilde{\omega} \nu \varepsilon \dot{\varepsilon} \rho \omega \tau \eta \theta \dot{\varepsilon} v \tau \omega \nu$ í $\pi 0 \theta \dot{\varepsilon} \sigma \varepsilon \omega v$, folios $133 \mathrm{v}-147 \mathrm{v}$ ), and the 'Founder's Typikon' of the

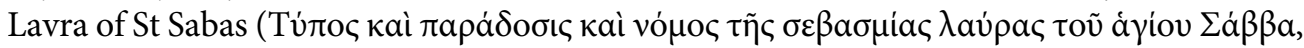
folios $148 \mathrm{r}-149 \mathrm{v}){ }^{76}$ The manuscript concludes with the order of services from Great Lent (folios 150r-175v), Holy Week (folios 175v-183r) and Easter (folios 183v-186r), but because of damage, the manuscript ends with liturgical prescriptions for Pentecost.

\section{Concluding remarks}

Apart from their importance to broader Byzantine liturgical studies, the two Greek manuscripts examined here present unique perspectives on the liturgical life of local Palestinian

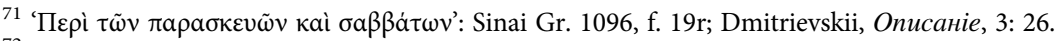

${ }^{72}$ Sinai Gr. 1096, f. 55r: Dmitrievskii, Onисаніе, 3: 34-5.

${ }^{73}$ Dmitrievskii, Onucarie, 3: 21-2 and 24-5. The general order was a development from that of cathedral Vespers in Jerusalem, where Egeria observed the procession to the cross at Golgotha at the end of Vespers. See Égérie, Journal de voyage, $238-40$ (24: $4-7)$.

${ }^{74}$ Sinai Gr. 1096, f. 55r: Dmitrievskii, Onисаніе, 3: 34-5.

75 'Суть же 3 церкви ... И ту есть гробъ святаго Савы посредіњ церквий тъх трій, вдалье отъ великія сажень 4; и есть теремець над гробомъ святаго Савы, учинено красно.' Venevitinov, Житье и хожденье Даниила, 54-5; Prokhorova, ed., 'Хождение игумена Даниила', 57-9; Denys Pringle, The Churches of the Crusader Kingdom of Jerusalem: a Corpus. 4 vols. (New York: Cambridge University Press, 1993-2009), 2: 259-60.

${ }^{76}$ This last work was edited separately by Dmitrievskii and was later included in the Dumbarton Oaks series on monastic foundation documents; Dmitrievskii, Onисанie, 1: 222-4; Fiaccadori, 'Sabas: Founder's Typikon', in Byzantine Monastic Foundation Documents, eds. Thomas and Constantinides Hero, 4: 1311-18.
} 
Christians who were praying in Greek during the period of crusader control of Jerusalem. Most striking, perhaps, is that both sources seem to be in denial about the secondary place assumed by Palestinian Christians on their own home territory and make almost no mention of Latins within the context of liturgical prayer. While this new situation that the local Orthodox Church encountered under the crusaders would affect the whole Orthodox Patriarchate, the response in the cathedral and monastic liturgical sources appears to differ.

In the cathedral source, the Anastasis Typikon in Hagios Stavros Gr. 43 (A.D. 1122), the copyist Basil the Hagiopolite makes a concerted effort to preserve local Jerusalem liturgical traditions in the face of an uncertain future. He insists upon the celebration of the Liturgy of St James on the most important holy days of the year and makes a clear distinction between the liturgical order of the Holy Sepulchre and the liturgical practices of the 'Romans' (i.e. the Byzantines in Constantinople). Again, whether it was fully possible to serve Holy Week and Easter in 1122 based on his manuscript is unknown. The witness of Abbot Daniel at the beginning of the twelfth century confirms the subordinate role of the Greek clergy, in this case monks and clergy from St Sabas Lavra without any sign of a Greek patriarch or bishop, in liturgical services at the Holy Sepulchre. The Life of Leontios, exiled patriarch of Jerusalem (c.1171-85), set at the end of the twelfth century, paints an equally bleak picture. During a rare visit to the Holy Land, he entered Jerusalem by night and prayed privately at the Anastasis, in order to avoid Latin authorities. $^{77}$

In the monastic source, the Sabaite Typikon Sinai Gr. 1096 (twelfth century), there seems to be little concern to abandon the liturgical practices of Jerusalem, as long as they respect the veneration of the founder, St Sabas, and are in accordance with Byzantine practice. The 'Testament of St Sabas' even admits Franks - as long as they and the other

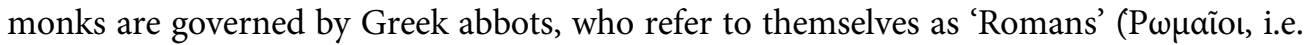
Byzantines). This monastic view conforms to the ideological policy of Constantinople's foremost canonist at the end of the twelfth century, Patriarch Theodore Balsamon. According to Balsamon: ' ... those boasting of an Orthodox life, whether they might be from the East, or from Alexandria, or elsewhere, are called Romans and must be governed according to the laws ... ${ }^{78}$ With such pronouncements, the fate of the Orthodox Patriarchate of Jerusalem was clear: if it wished to remain Orthodox in the eyes of the Byzantines, it had to be like Constantinople, even if this meant losing its own liturgical traditions.

While the liturgical prescriptions of both the cathedral and monastic manuscripts examined in this paper function as if the greatest concern were the relationship of Jerusalem and Constantinople, the context of the Crusader Kingdom is much more apparent in the regulation of daily life. Franks are never mentioned in the liturgical texts, but they are permitted to pray on their own and receive hospitality in Greek monasteries. Nikon of the Black Mountain, a monk living at the beginning of the twelfth century near Antioch,

\footnotetext{
${ }^{77}$ Dimitris Tsougarakis, ed., The Life of Leontios Patriarch of Jerusalem. The Medieval Mediterranean 2 (Leiden: Brill, 1993).

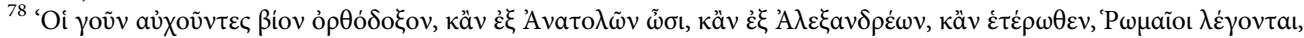

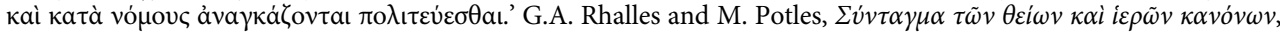

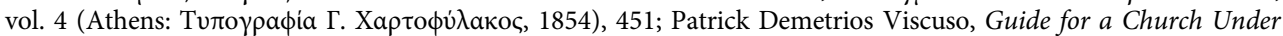
Islām: the Sixty-Six Canonical Questions Attributed to Theodōros Balsamōn. A Translation of the Ecumenical Patriarchate's Twelfth-Century Guidance to the Patriarchate of Alexandria (Brookline: Holy Cross Orthodox Press, 2014), 72-3 (response to question 4).
} 
encountered crusaders and expressed certain reservations about them in his Taktikon, a collection of texts concerning monastic regulation and liturgical order. ${ }^{79}$ Regarding hospitality, Nikon mentions foreign monks or laymen passing through the area on their way to Jerusalem. While the foreign monks are allowed to stay for three days, Franks are placed in a separate category:

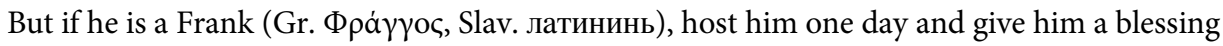
and dismiss him. But if he is ill, keep him until he recovers. But nevertheless, if it is also appropriate for the Franks to rest for the three days and it is necessary for the salvation of soul and body, let it be so. But to all persons let whatever is pleasing to God be; but at least let nothing unpleasing to God prevail. ${ }^{80}$

More specific instruction is given to the monastery guest-master regarding meals with Franks:

The host of the hospice should not eat separately apart from the foreign monks or lay persons, unless those being offered hospitality are many and he wishes to serve them, except for the Franks due to the unsoundness of [their] thinking. Nevertheless [he should eat] even with these, if [their] thinking is sound. ${ }^{81}$

Thus, Franks were welcome, but reluctantly and with suspicion. ${ }^{82}$ Nevertheless, they are never mentioned in the liturgical Typikon copied by Nikon for another monastery in the region of Antioch. ${ }^{83}$ The mention of Franks in the context of monastic regulation and their complete absence from related liturgical prescriptions - is consistent with the Sabaite Typikon in Sinai Gr. 1096. Thus, sharing the dinner table was acceptable, but there is no regulation - nor even mention - of sharing the Eucharistic table. Although 'cross-fertilisation' existed in various facets of life between the different linguistic and religious groups in the crusader kingdom in the twelfth century, including exchanges between Greek and Latin literature, ${ }^{84}$ with regard to liturgy Greek sources are silent. Evidence of 'inter-ritual concelebration' before the crusaders in Jerusalem, and in Antioch upon the

\footnotetext{
${ }^{79}$ Christian Hannick and others, eds., Das Taktikon des Nikon vom Schwarzen Berge. Griechischer Text und kirchenslavische Übersetzung des 14. Jahrhunderts. Monumenta linguae Slavicae dialecti veteris 62. 2 vols. (Freiburg im Breisgau: Weiher Verlag, 2014), 1: xxv-xxxix.

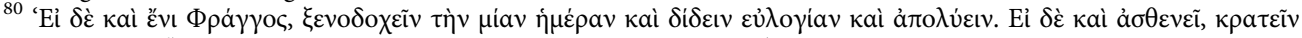

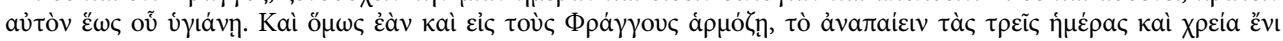

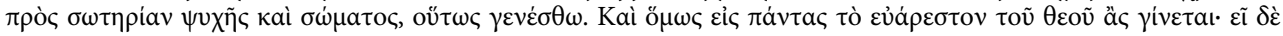

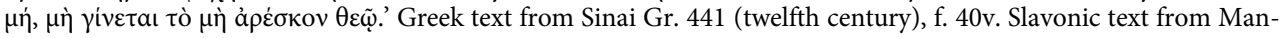
astir Sveta Trojica Pljevlja, [Serbia], 12 (fourteenth century), ff. $31 \mathrm{r}-31 \mathrm{v}$, and Nacionalen muzej 'Rilski manastir', [Bulgaria], 1/16 (fourteenth century), f. 40r. See 'Logos 2/Slovo 2', in Hannick and others, eds., Das Taktikon des Nikon vom Schwarzen Berge, 1: 142-3 (\$9). English translation from '21. Roidion: Typikon of Nikon of the Black Mountain for the Monastery and Hospice of the Mother of God tou Roidiou', trans. Robert Allison, in Byzantine Monastic Foundation Documents, eds. Thomas and Constantinides Hero, 1: 425-39 (432 (\$3)).

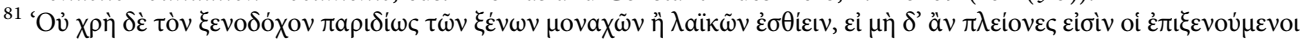

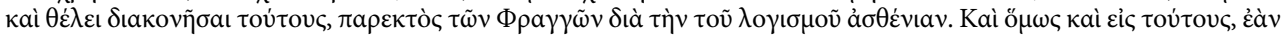

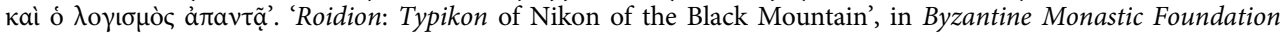
Documents, eds. Thomas and Constantinides Hero, 1: $432(\$ 4)$.

${ }^{82}$ See 'Roidion: Typikon of Nikon of the Black Mountain', in Byzantine Monastic Foundation Documents, eds. Thomas and Constantinides Hero, 1: 427 and 438, n. B3.

${ }^{83}$ See Hannick and others, eds., Das Taktikon des Nikon vom Schwarzen Berge, 1: 48-135; '20. Black Mountain: Regulations of Nikon of the Black Mountain', 1: 377-424 (377 and 383, n. 1). The dating of the Typikon found in 'Logos 1/ Slovo 1' in Nikon's Taktikon is not certain, although it may pre-date the crusades.

${ }^{84}$ Krijnie Ciggaar, 'Manuscripts as Intermediaries: the Crusader States and Literary Cross-Fertilization', in East and West in the Crusader States: Context - Contacts - Confrontations. Acta of the Congress held at Hernen Castle in May 1993, eds. Krijnie Ciggaar, Adelbert Davids and Herman Teule. Orientalia Lovaniensia Analecta 75 (Leuven: Peeters, 1996), 131-51.
} 
arrival of the crusaders, does exist, but the polemics between the Greeks and Franks and questions of control over holy places seem to have eliminated any possibility of this in the twelfth century, making any mention of common worship and prayer in liturgical texts redundant. ${ }^{85}$ Despite the historical, political and cultural context, which made it impossible for Greek- and Latin-praying Christians to avoid one another in twelfth-century crusader Jerusalem, the liturgy appears to be one place where the Orthodox Christians in the Holy Land sought to have some peace from the Latins of the crusader kingdoms and were more interested in strengthening ties with the Church in Constantinople.

\section{Notes on contributor}

Daniel Galadza is Assistant Professor to the Chair of Liturgical Studies and Sacramental Theology at the University of Vienna, as well as National Research Partner at the Division of Byzantine Research in the Austrian Academy of Sciences. In 2016-17 he was Visiting Professor at the Pontifical Oriental Institute in Rome.

\footnotetext{
${ }^{85}$ See Bernard Hamilton, The Latin Church in the Crusader States: the Secular Church (London: Variorum Publications, 1980), 1-17 and 159-87. McCormick, Charlemagne's Survey of the Holy Land, 176-7, mentions the earlier controversy over the Filioque in Jerusalem, when Michael the Synkellos (c.761-846) was sent to Rome to,

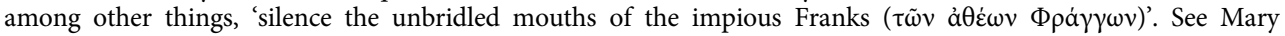
B. Cunningham, ed. and trans., The Life of Michael the Synkellos. Belfast Byzantine texts and translations 1 (Belfast: Queen's University of Belfast, 1991), 56. See also Tia Kolbaba, 'Byzantines, Armenians, and Latins: Unleavened Bread and Heresy in the Tenth Century', in Orthodox Constructions of the West, eds. George M. Demacopoulos and Aristotle Papanikolaou (New York: Fordham University Press, 2013), 45-57.
} 